\title{
Effect of Sport Education on Stress and Assertiveness of Middle School Students
}

\author{
Ahmet Gonener ${ }^{1}$ \\ ${ }^{1}$ Faculty of Sport Sciences, Kocaeli University, Kocaeli, Turkey \\ Correspondence: Ahmet Gonener, Faculty of Sport Sciences, Kocaeli University, Kocaeli 41380, Turkey. E-mail: \\ ahmetgonener123@gmail.com
}

Received: December 21, 2019

Accepted: February 1, $2020 \quad$ Online Published: April 18, 2020

doi:10.5539/ies.v13n5p108

URL: https://doi.org/10.5539/ies.v13n5p108

\begin{abstract}
Purpose: The aim of this study was to investigate the effect of basic tennis education on stress and assertiveness levels among middle school students.

Material: The study group consisted of a total of 120 students, 60 females and 60 males, aged 9-11 years. The Rathus Assertiveness Schedule and the Perceived Stress Scale for Children were used as data collection tools, and a questionnaire was administered to gather demographic information of the participants. The data were transferred to IBM SPSS 25.0 package program and analyzed using paired samples t-test.

Results: As a result of the statistical analyses performed on the data obtained in the pretest and posttest at $p<0.05$ significance level, significant differences were found between assertiveness and stress scores of the male participants; between assertiveness and stress scores of the female participants; and between assertiveness and stress scores of the whole study group regardless of gender differences.

Conclusions: Pretest and posttest results revealed that there was a significant effect of basic tennis training on the increase in assertiveness levels and the decrease in stress levels among female and male students $(p<0.05)$.
\end{abstract}

Keywords: education, tennis, assertiveness, stress

\section{Introduction}

Assertiveness, shyness, and aggression are popular and frequently used concepts of today. While assertiveness is defined as protecting oneself and one's rights and expressing oneself without harming the rights of others, assertiveness is defined as a way of conceptualizing one's own perceptions about commitment, control, and challenge that help people manage themselves in stressful situations (Maddi \& Khoshaba, 1994). Assertiveness is a life skill that can increase through activities, develops self-confidence and social communication skills of individuals to enable them to exercise their rights and to respect the rights of others, and ultimately increases life satisfaction and happiness in life (Lin et al., 2004). Assertive individuals have no difficulty in establishing close relationships with others, can prevent others from abusing them, and may have a wide range of positive and negative feelings without violating the rights of others (Avşar \& Alkaya, 2017).

It is important that adults who frequently communicate and interact with children have the skills to establish healthy individual relationships because a child's growth as an individual, who has a solid self-confidence, intrinsic control, advanced social skills such as responsibility, solidarity, sharing, and cooperation, and can establish positive relationships with others, is shaped with the help of its interactions with family members and the environment. The effect of the family is critical on the psycho-social and personality developments in childhood. Individuals can acquire assertive behavior skills especially through childhood education. For school age children, their friends, school, course success and physical competencies are very important (Gönener \& Pek, 2009). In early childhood, children take critical steps in the stages of both emotional and cognitive developments. Children in this period can describe basic emotional expressions (happiness, anger, sadness, fear) (Denham, 1986). The appropriate assertiveness education provided to children from early ages helps them choose the appropriate types of behavior for each situation, build self-confidence, and express their thoughts and feelings (Manesh et al., 2015).

Accordingly, it is necessary to organize supportive education sessions for adults with children in early childhood, where development is the fastest and most affected by the environment. The concept of stress, on the other hand, is defined as a significant imbalance between physical or psychological desire and response capacity in cases where 
a request is not satisfied (McGrath, 1970). Many education techniques are available to reduce cognitive stress and anxiety. The most known ones are relaxation response, autogenic exercise, systematic desensitization, stress management, and stress immunization (Wolpe, 1968; Schultz \& Luthe,1969; Meichenbaum \& Deffenbacher, 1988; Weinberg \& Gould, 2015).

The only purpose of education should not be to teach children some subjects and prepare them for professional life. Despite the wrong perception that schools should only teach theoretically-weighted courses, the ultimate task of schools is to create a learning environment and to gain students daily physical activity habit (Şentürk, Y1lmaz, \& Gönener, 2015). In addition, what should be one of the basic functions of education is to prepare students for communication, which is the most important part of human relations, and situations that may be encountered in daily life (Kaf, 1999). In order for society to gain good and strong people, and thus to be a healthy one, people need to have a good quality education, which will be achieved with the help of discussing, understanding and experiencing. Such education will help healthy individuals to be gained in society. Various studies have shown that the participation of individuals in sports education contributes positively to their cognitive, affective and psychomotor developments. It is clear that sport plays a role in helping them being an assertive individual, and has a direct effect on the multidimensional development of individuals by providing positive development in self-confidence and self-control levels (Öztürk, Efe, \& Koparan, 2007; García-López \& Gutiérrez, 2015). It is emphasized that applied physical education is characterized by meaningful activities, can be used as a means of coping with some psychological and social problems, assertiveness is one of the goals in such activities, and it should be considered as education in itself (Etzel-Wise \& Mears, 2004).

In the studies conducted between those who do sports and those who do not, it was found that those who did sports are livelier, more extroverted, more hardworking, more patient, more ready to establish social relations, more emotionally balanced, and adapt to a new situation more easily than those who did not do sports (Tiryaki, 1991). In this context, it can be thought that sports activities are effective on assertiveness levels among individuals (Büyükyazı, Saraçoğlu, Karadeniz, Çamlıyer, \& Çamlıyer, 2003). In the light of above-mentioned information, the hypothesis of our study was based on the assumption that basic tennis education will have a positive effect on stress and assertiveness levels among secondary school students.

\section{Method}

\subsection{Research Sample}

The study group consisted of a total of 120 students, 60 females and 60 males, aged 9-11 years. The study group was given basic tennis education three days a week for 1.5 hours and the educations continued for 16 weeks. The educations were done in Izmit Tennis Club.

\subsection{Research Design}

The aim of this study was to investigate the effect of basic tennis education on stress and assertiveness levels among middle school students. The experimental study method was used. Pre-test and post-test after 16-week-education were planned. 


\subsection{Training Programme}

Table 1. General training programme

\begin{tabular}{|c|c|c|c|}
\hline General training programme & & & \\
\hline 1st-4th Weeks & 5th-8th Weeks & 9th-12th Weeks & 13th-16th Weeks \\
\hline $\begin{array}{l}\text { General warm-up: } \\
\text { ', jogging } \\
5 \text { ' stretching } \\
\text { 10' physical education } \\
\text { games }\end{array}$ & $\begin{array}{l}\text { General warm-up: } \\
10 \text { ' jogging } \\
5 \text { ' stretching } \\
10 \text { ' physical education games } \\
\text { 3' rest }\end{array}$ & $\begin{array}{l}\text { General warm-up: } 10 \text { ' jogging } \\
5 \text { ' stretching } \\
10 \text { ' physical education games } \\
\text { 3' rest }\end{array}$ & $\begin{array}{l}\text { General warm-up: } 10 \text { ' jogging } \\
\text { ' stretching } \\
\text { 10' physical education games } \\
\text { 3' rest }\end{array}$ \\
\hline $\begin{array}{l}\text { Main unit: } \\
\text { 10' Forehand-backhand grip } \\
\text { techniques } \\
\text { 3' rest } \\
\text { 10' ball bouncing with racket } \\
\text { 3' rest } \\
\text { 10' mini court forehand } \\
\text { block } \\
\text { 3' rest } \\
\text { 10' mini court backhand } \\
\text { block }\end{array}$ & $\begin{array}{l}\text { Main unit: } \\
15 \text { ' ladder footwork training } \\
2 \text { ' rest } \\
5 \text { ' short court block forehand } \\
5 \text { ' short court block backhand } \\
\text { '' rest } \\
10 \text { 'block forehand-backhand } \\
\text { parallel to target }\end{array}$ & $\begin{array}{l}\text { Main unit: } \\
10 \text { ' serve positioning, ball throwing } \\
\text { and catching for serving } \\
5 \text { ' serving } \\
\text { '' rest } \\
10 \text { ' half court rally } \\
\text { 2' rest } \\
10 \text { ' baseline rally }\end{array}$ & $\begin{array}{l}\text { Main unit: } \\
10 \text { ' serve-return } \\
10 \text { ' half court rally } \\
2 \text { ' rest } \\
10 \text { ' baseline rally } \\
10 \text { ' crosscourt rally }\end{array}$ \\
\hline $\begin{array}{l}\text { Cooldown: } \\
\text { 5' cooldown-stretching }\end{array}$ & $\begin{array}{l}\text { Cooldown: } \\
\text { 10' cooldown-physical education } \\
\text { games-stretching }\end{array}$ & $\begin{array}{l}\text { Cooldown: } \\
10^{\prime} \text { cooldown-physical education } \\
\text { games-stretching }\end{array}$ & $\begin{array}{l}\text { Cooldown: } \\
10, \quad \text { cooldown-physical } \\
\text { education games-stretching }\end{array}$ \\
\hline Total duration: $74^{\prime}$ & Total duration:72' & Total duration: $77^{\prime}$ & Total durations: $80^{\prime}$ \\
\hline
\end{tabular}

\subsection{Data Collection}

The Rathus Assertiveness Schedule and the Perceived Stress Scale for Children were used as data collection tools, and a questionnaire was administered to gather demographic information of the participants. The scales were administered to the students, and the data were collected by the researcher himself. Before the administration of the scales, the students were informed about the aim and context of the study. Each scale was administered for 10 minutes. It is an inventory called "The Rathus Assertiveness Schedule," that was generated in the USA (Rathus, 1973). It is also adopted to Turkish (Voltan, 1980). This inventory identifies the degree of assertiveness in the behavioral norms of individuals. It is an inventory that consists of 30 positive and negative items to determine the assertiveness of students. The RAS consists of 6-point Likert-type statements that can be scored as "Very much like me," "Rather like me," "Slightly like me," "Slightly unlike me," "Rather unlike me," and "Very much unlike me." While the top score one can obtain is 30 in the shyness dimension, it is 180 in the assertiveness dimension. There are 13 positive statements in the scale, which are items $3,6,7,8,10,18,20,21,22,25,27,28$, and 29 . The scores of these positive statements are "Very much like me" - 6 points, "Rather like me" -5 points, "Slightly like me" - 4 points, "Slightly unlike me" - 3 points, "Rather unlike me" - 2 points, and "Very much unlike me" - 1 point. On the other hand, there are 17 negative statements in the scale, which are items 1, 2, 4, 5, 9, 11, 12, 13, 14, 15, 16, $17,19,23,24,26$, and 30 . Negative statements are coded as the reverse of positive ones and scored reversely. The sum of scores of the participants in each statement was interpreted according to the following grouping, and it was decided on the conditions of assertiveness or shyness. The grouping is done in a way that the one with a score $30-80$ is shy; the one with a score $80-130$ is moderately shy; the one with a score $130-180$ is assertive (Hoşgör, Arslan-Kurtuluş, Gündüz-Hoşgör, \& Selma, 2017). The Perceived Stress Scale for Children (8-11 years) was used in the study (Snoeren-Hoefnagels, 2014; Oral \& Ersan, 2017). This is a unidimensional and 4-point Likert-type scale which consists of 9 items. Higher scores on the scale mean higher the stress level one has. The total score that can be obtained by the participants on the scale, which has no reverse item, ranges from 0 to 27 points.

\subsection{Data Analysis}

IBM SPSS 25 for Windows (Statistical Package for the Social Sciences) statistical program was utilized for the analysis and interpretation of the data collected employing the scales. The Kolmogorov-Smirnov test was used to determine whether the data obtained after the calculation of descriptive statistics (mean, standard deviation, frequency, percentage) satisfied normal distribution conditions. Since the data satisfied normal distribution 
conditions, the statistical procedures continued with parametric tests. Paired Samples T-Test was used to make pretest and posttest comparisons of the data obtained from the participants. The significance level was taken as $\mathrm{p}<0.05$.

\section{Results}

The findings obtained in this study are presented below.

Table 2. Distribution of the student's ages.

\begin{tabular}{cccccc}
\hline & Gender & $\mathrm{n}$ & Mean $\pm \mathrm{SD}$ & min. & max. \\
\hline \multirow{4}{*}{ Age } & Male & 60 & $10.35 \pm 0.89$ & 9 & 11 \\
& Female & 60 & $10.23 \pm 0.99$ & 9 & 11 \\
& Total & 120 & $10.29 \pm 0.94$ & 9 & 11 \\
\hline
\end{tabular}

Table 3. Distribution of the study group's responses to demographic questions

\begin{tabular}{|c|c|c|c|c|c|}
\hline \multirow{2}{*}{ QUESTIONS } & & \multicolumn{2}{|c|}{ MALE } & \multicolumn{2}{|c|}{ FEMALE } \\
\hline & & $\mathbf{N}$ & $\%$ & $\mathbf{n}$ & $\%$ \\
\hline \multirow{2}{*}{ What is your mother's education level? } & University & 55 & 91.7 & 49 & 81,7 \\
\hline & High School & 5 & 8.3 & 11 & 18,3 \\
\hline \multirow{3}{*}{ What is your father's education level? } & University & 41 & 68.3 & 44 & 73,3 \\
\hline & High School & 18 & 30.0 & 15 & 25.0 \\
\hline & Middle School & 1 & 1.7 & 1 & 1.7 \\
\hline \multirow{4}{*}{ How many siblings do you have? } & Only child & 22 & 36.7 & 16 & 26.7 \\
\hline & One & 33 & 55.0 & 38 & 63.3 \\
\hline & Two & 4 & 6.7 & 2 & 3.3 \\
\hline & Three or more & 1 & 1.7 & 4 & 6.7 \\
\hline \multirow{3}{*}{ What is the property status of the house you currently live? } & Homeowner & 49 & 81.7 & 46 & 76.7 \\
\hline & Lodgement & 5 & 8.3 & 5 & 8.3 \\
\hline & For rent & 6 & 10.0 & 9 & 15.0 \\
\hline \multirow{2}{*}{ Are your parents alive? } & Both are alive & 59 & 98.3 & 60 & 100 \\
\hline & Only my father is alive & 1 & 1.7 & & \\
\hline \multirow{5}{*}{ What is the income level of your family? } & Less than TRY 2000 & & & 1 & 1.7 \\
\hline & More than TRY 2001 & 2 & 3.3 & 1 & 1.7 \\
\hline & More than TRY 2500 & 7 & 11.7 & 10 & 16.7 \\
\hline & More than TRY 3000 & 19 & 31.7 & 19 & 31.7 \\
\hline & More than TRY 3500s & 32 & 53.3 & 29 & 48.3 \\
\hline
\end{tabular}

$91.7 \%$ of males and $81.7 \%$ of females have mothers with university degree; $68.3 \%$ of males and $73.3 \%$ of females have fathers with university degree; $55 \%$ of males and $63.3 \%$ of females have only one sibling; $81.7 \%$ of males and $76.7 \%$ of females live in their own homes; and parents of $98.3 \%$ of males and $100 \%$ of females are alive. $53.3 \%$ of males and $48.3 \%$ of females had a family income of $3500 \mathrm{TL}$ and over. 
Table 4. Descriptive statistics of male and female participants' Rathus assertiveness schedule and perceived stress scale scores

\begin{tabular}{|c|c|c|c|c|c|}
\hline & & $\mathrm{n}$ & Mean \pm SD & Min & Max \\
\hline \multirow{6}{*}{ Scores on the Rathus Assertiveness Schedule } & Male pretest & 60 & $111.43 \pm 9.56$ & 89 & 136 \\
\hline & Female pretest & 60 & $112.10 \pm 7.6$ & 95 & 135 \\
\hline & Total pretest & 120 & $111.76 \pm 8.61$ & 89 & 136 \\
\hline & Male posttest & 60 & $125.00 \pm 9.26$ & 107 & 144 \\
\hline & Female posttest & 60 & $122.81 \pm 13.04$ & 89 & 145 \\
\hline & Total posttest & 120 & $123.90 \pm 11.32$ & 89 & 145 \\
\hline \multirow{6}{*}{ Scores on the Perceived Stress Scale for Children } & Male pretest & 60 & $17.06 \pm 4.2$ & 10 & 25 \\
\hline & Female pretest & 60 & $17.33 \pm 4.0$ & 12 & 26 \\
\hline & Total pretest & 120 & $17.20 \pm 4.09$ & 10 & 26 \\
\hline & Male posttest & 60 & $14.53 \pm 3.86$ & 6 & 22 \\
\hline & Female posttest & 60 & $14.91 \pm 4.24$ & 7 & 24 \\
\hline & Total posttest & 120 & $14.72 \pm 4.05$ & 6 & 24 \\
\hline
\end{tabular}

The mean age was found to be $10.35 \pm 0.89$ for males and $10.23 \pm 0.99$ for females. While males' pretest and posttest

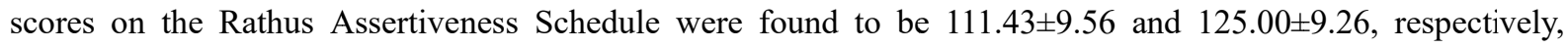
females' scores were found to be $112.10 \pm 7.60$ and $122.81 \pm 13.04$, respectively.

On the other hand, males' pretest and posttest perceived stress scores were found to be $17.06 \pm 4.2$ and $14.53 \pm 3.86$, respectively while the scores of females in the same parameter were $17.33 \pm 4.0$ and $14.91 \pm 4.24$, respectively.

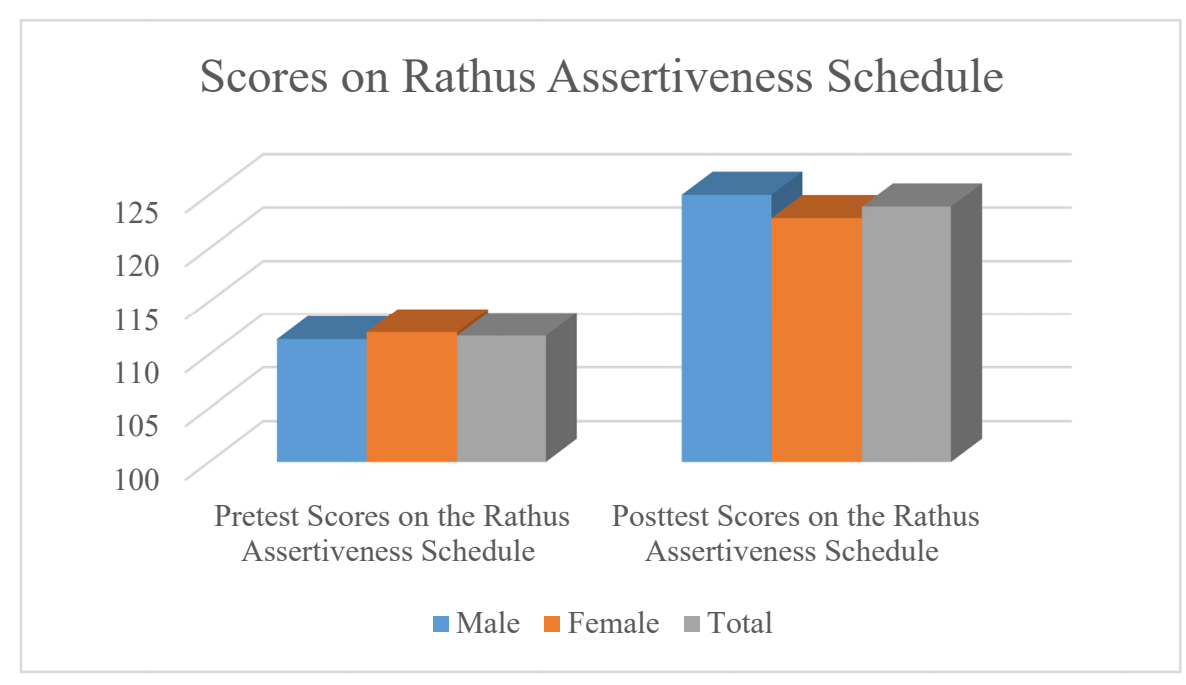

Figure 1. Scores of Rathus assertiveness schedule 


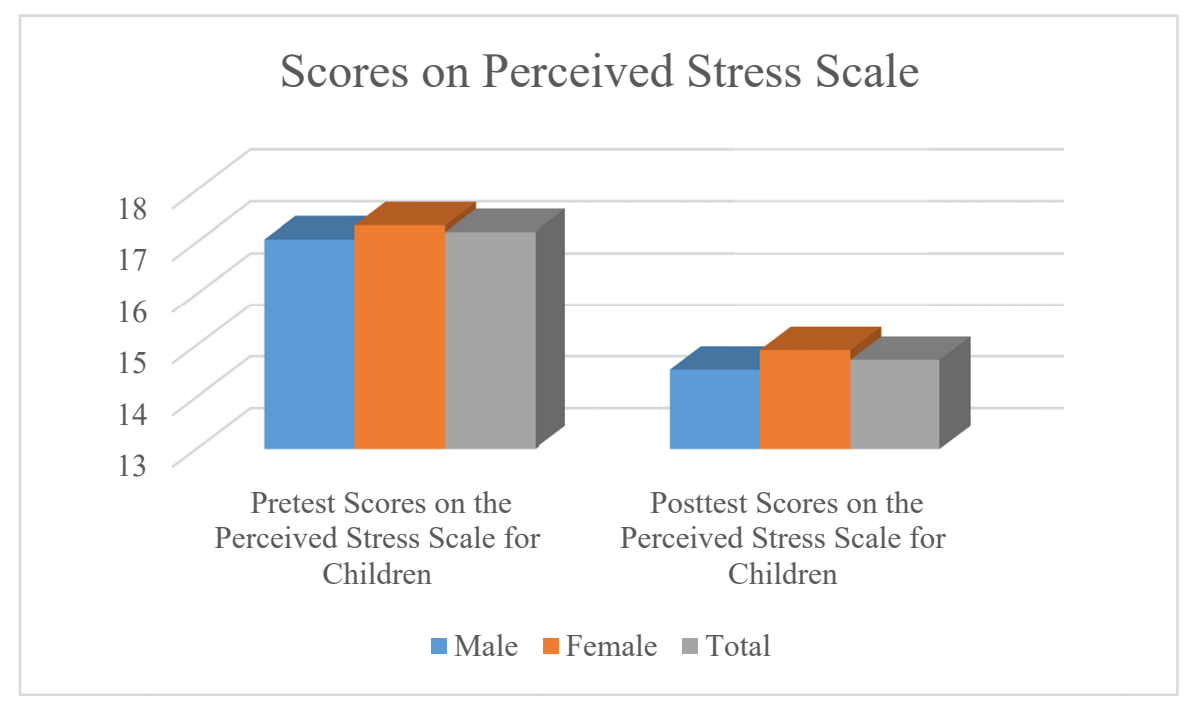

Figure 2. Scores on perceived stress scale

Table 5. Results of pre-test and post-test scores of male participants

\begin{tabular}{lcc}
\hline Variable & $\mathrm{t}$ & $\mathrm{p}$ \\
\hline Scores on the Rathus Assertiveness Schedule & 7.511 & $.000^{*}$ \\
Scores on the Perceived Stress Scale for Children & 8.069 & $.000^{*}$ \\
\hline
\end{tabular}

A significant difference was found between pretest and posttest scores of males in the assertiveness and stress variables at $\mathrm{p}<0.05$ level.

Table 6. Results of pre-test and post-test scores of female participants

\begin{tabular}{lcc}
\hline Variable & $\mathrm{t}$ & $\mathrm{p}$ \\
\hline Scores on the Rathus Assertiveness Schedule & 5.421 & $.000^{*}$ \\
Scores on the Perceived Stress Scale for Children & 7.679 & $.000^{*}$ \\
\hline
\end{tabular}

A significant difference was found between pretest and posttest scores of females in the assertiveness and stress variables at $\mathrm{p}<0.05$ level.

Table 7. Results of pre-test and post-test scores of whole participants

\begin{tabular}{lcc}
\hline Variable & $\mathrm{t}$ & $\mathrm{p}$ \\
\hline Scores on the Rathus Assertiveness Schedule & 9.064 & $.000^{*}$ \\
Scores on the Perceived Stress Scale for Children & 11.179 & $.000^{*}$ \\
\hline
\end{tabular}

It is indicated that a significant difference was found between pretest and posttest scores of the whole study group in the assertiveness and stress variables at $\mathrm{p}<0.05$ level.

\section{Discussion}

Pretest and posttest results in our study revealed that there was a significant effect of basic tennis education on the increase in assertiveness levels and the decrease in stress levels among female and male students $(p<0.05)$. Such results may infer that tennis education positively affects students' personal development. Previous studies in the literature emphasize that play-based and physical education and sports education contributes significantly to students' psychosocial development, improve assertiveness, and develop students' personal communication skills (Etzel-Wise \& Mears, 2004; Durualp \& Aral, 2010). In a study in which the effects of the classes with play-based learning approach and traditional learning approach on children's freedom levels were observed, it was found that autonomous behaviors of children were more flexible in classes with play-based learning approach and children restricted themselves more in classes with traditional learning approach (Walsh et al, 2006). 
The guidance from families is as important as children's wishes in their tendency to sports education and playing. Families may, of course, desire their children to do sports, albeit another important factor is parental expectations for their children's success. Sports success may lie under the concepts of social skills or cognitive development. In a study conducted on students aged 11-14, it was stated that handball exercises significantly increased the assertiveness of students and that more sports education improved students' skills of comprehension, adoption of different roles, and multi-faceted thinking (García-López \& Gutiérrez, 2015). In a study conducted on children aged 12-14, it was stated that children doing sports were more assertive than those who did not do sports (Özşaker, 2013). Besides, in their study conducted on middle school students, it is stated that the emotional regulation of students doing sports showed a significant difference compared to the ones who did not do sports and that sports had a positive effect on emotional regulation (Çebi, Yamak, \& Öztürk, 2016). Following an approach that will cover more than one sports branch in sports education for particularly elementary and middle school students contributes to their motor development and goal orientation, which support children's participation in physical activities. Besides, it is clear that sports education given to children by experts significantly supports children's appropriate physical and psychological developments, which will enable them to become healthy individuals and a part of the society, and in this context, sports and sports education have significant contributions to students' assertiveness levels and social development.

In addition to the age group in our study, there are also studies examining the effects of sports education on assertiveness among different age groups. In a study conducted on male athletes aged 13-19 who had a sports history of at least one year, it was determined that these athletes had assertive personalities (Bavl1, 2009). In a study conducted with female students aged 14-16 who had basic handball education, it was stated that handball exercises applied for 9 months significantly increased the social competence and assertiveness of the students (Öztürk et al., 2007). It can be seen that sports education has positive effects on the assertiveness and social competence in not only a certain age group but also many age groups. Assertiveness training and stress control exercises should be done in addition to sports education. Sports education and mental exercises should be approached from a holistic perspective and must be included in education programs of students. Connelly and Rotella (1991) stated that assertiveness education had an important role in addressing and preventing unresolved communication problems and that they believed that education would support the development of assertiveness skills and personal development.

Based on this idea, it is thought that any kind of education that can increase assertiveness in younger age groups can improve the assertiveness of children and help them take a more active role in individual and group activities. It can be said that factors such as the traditional cultural elements of our society, authoritarian parental attitudes, repressive raising methods, and rapid social and cultural changes cause various problems in the development of individuals. Such challenges can be thought to affect adversely one's ability to express itself and to struggle with difficulties. For this reason, families and educational institutions should directly support the students to receive sports education. It should be stated that implementing a sports education program, covering any kind of supports to ensure the positive development of students who are in developmental age, will be helpful.

In order to improve the social development of students in the formal education process and increase their level of assertiveness, it may be necessary to add and increase the frequency of play-based sports education in annual curricula and to update the existing plans and programs considering such points. Studies can be designed with different methodologies to determine whether the developments obtained after the periodic education are permanent or temporary so that the importance of the continuity of sports education can be revealed. Longitudinal studies can be conducted to uncover the effects of long-term sports education on different personality traits. In addition to the age group in our study, it is useful to conduct similar studies in different age groups and compare the results.

\section{References}

Avşar, F., \& Alkaya, S. A. (2017). The effectiveness of assertiveness training for school-aged children on bullying and assertiveness level. Journal of pediatric nursing, 36, 186-190. https://doi.org/10.1016/j.pedn.2017.06.020

Bavlı, Ö. (2009). Gelişim çă̆ındaki sporcuların atılganlık düzeyleri ile yaralanma durumu ilişkilerinin incelenmesi. Firat Üniversitesi Sağllk Bilimleri Tıp Dergisi, 23(1), 7-19

Büyükyazı, G., Saraçoğlu, S., Karadeniz, G., Çamlıyer, H., \& Çamlıyer, H., (2003). Sedanterler ile veteran atletlerin çeşitli değişkenlere göre atılganlık düzeylerinin karşılaştırılması. Gazi Beden Eğitimi Spor Bilimleri Dergisi, 8(4), 13-24. https://doi.org/10.1501/sporm_0000000160

Çebi, M., Yamak, B., \& Öztürk, M. (2016). 11-14 yaş çağındaki çocukların spor yapma alışkanlığının duygu 
kontrolü üzerine etkilerinin incelenmesi. Amasya Üniversitesi Ĕgitim Fakültesi Dergisi, 5(2), 468-482.

Connelly, D., \& Rotella, R. J. (1991). The social psychology of assertive communication: Issues in teaching assertiveness skills to athletes. The sport psychologist, 5(1), 73-87. https://doi.org/10.1123/tsp.5.1.73

Denham, S. A. (1986) Social cognition, prosocial behavior, and emotion in preschoolers: Contextual validation. Child Development, 57(1) 194-201. https://doi.org/10.2307/1130651

Durualp, E., \& Aral, N. (2010). Altı yaşındaki çocukların sosyal becerilerine oyun temelli sosyal beceri eğitiminin etkisinin incelenmesi. Hacettepe Üniversitesi Ĕgitim Fakültesi Dergisi, 39, 160-172. https://doi.org/10.18506/anemon.453737

Etzel-Wise, D., \& Mears, B. (2004). Adapted physical education and therapeutic recreation in schools. Intervention in School and Clinic, 39(4), 223-232. https://doi.org/10.1177/10534512040390040401

García-López, L. M., \& Gutiérrez, D. (2015). The effects of a sport education season on empathy and assertiveness. Physical Education and Sport Pedagogy, 20(1), 1-16. https://doi.org/10.1080/17408989.2013.780592

Gönener, D., \& Pek, H. (2009). Okul yaş dönemi çocuğu olan ebeveynlerin hastalık ve hastaneye yatma durumunda "Ebeveynlerin endişe kaynakları ölçeği"nin geliştirilmesi ve çocukların endişe kaynakları ile etkileşimi. Gazintep Tip Dergisi, 15(1), 31-40.

Hoşgör, H., Arslan-Kurtuluş, S., Gündüz-Hoşgör, D., \& Selma, S. (2016). Üniversite öğrencilerinin atilganlik düzeylerinin belirlenmesi: Sağlik bilimleri fakültesi örneği. Akademik Sosyal Araştırmalar Dergisi, 4(32), 430-441. https://doi.org/10.16992/asos.3472

Kaf, Ö. (1999). Hayat bilgisi dersinde bazı sosyal becerilerin kazandırılmasında yaratıcı drama yönteminin etkisi. Çukurova Üniversitesi Sosyal Bilimler Enstitüsü Dergisi, 6, 173-184. https://doi.org/10.12780/uusbd139

Lin, Y. R., Shiah, I. S., Chang, Y. C., Lai, T. J., Wang, K. Y., \& Chou, K. R. (2004). Evaluation of an assertiveness training program on nursing and medical students' assertiveness, self-esteem, and interpersonal communication satisfaction. Nurse education today, 24(8), 656-665. https://doi.org/10.1016/j.nedt.2004.09.004

Maddi, S. R., \& Khoshaba, D. M. (1994). Hardiness and mental health. Journal of personality Assessment, 63(2), 265-274. https://doi.org/10.1207/s15327752jpa6302_6

Manesh, R. S., Fallahzadeh, S., Panah, M. S. E., Koochehbiuki, N., Arabi, A., \& Sahami, M. A. (2015). The effectiveness of assertiveness training on social anxiety of health volunteers of Yazd. Psychology, 6, 782. https://doi.org/10.4236/psych.2015.66077

McGrath, J. E. (1970). Major methodological issues. Social and psychological factors in stress (pp. 19-49). New York: Hold, Rinehart \& Winston.

Meichenbaum, D. H., \& Deffenbacher, J. L. (1988). Stress inoculation training. The Counseling Psychologist, 16(1), 69-90. https://doi.org/10.1177/0011000088161005

Oral, T., \& Ersan, C. (2017). Çocuklarda (8-11 yaş) algıllanan stres ölçeğinin Türkçe'ye uyarlama çalışması. Selçuk Üniversitesi Edebiyat Fakültesi Dergisi, 37, 419-428. https://doi.org/10.21497/sefad.328629

Özşaker, M. (2013). Assertiveness and self-esteem in Turkish adolescents: A study on athletes and nonathletes. International Journal on Disability and Human Development, 12(1), 61-66. https://doi.org/10.1515/ijdhd-2012-0126

Öztürk, F., Efe, M., \& Koparan, Ş. (2007). 14-16 yaş grubu kızlarda hentbol çalışmalarının sosyal yetkinlik beklentisi ve atılganlık üzerine etkisi. Spor Bilimleri Dergisi, 18(4), 147-155. https://doi.org/10.1501/sporm_0000000123

Rathus, S. A. (1973). A 30-item schedule for assessing assertive behavior. Behavior therapy, 4(3), 398-406. https://doi.org/10.1016/s0005-7894(73)80120-0

Schultz, J. H., \& Luthe, W. (1969). Autogenic therapy (Vol. 1). New York: Grune \& Stratton

Şentürk, U., Yılmaz, A., \& Gönener, U. (2015). Sınıf öğretmenlerinin oyun ve fiziki etkinlikler dersi ile ilgili görüş̧ ve uygulamaları. Spor Yönetimi ve Bilgi Teknolojileri, 10(2), 22-30. https://doi.org/10.17121/ressjournal.400

Snoeren, F., \& Hoefnagels, C. (2014). Measuring perceived social support and perceived stress among primary school children in The Netherlands. Child indicators research, 7(3), 473-486. 
https://doi.org/10.1007/s12187-013-9200-z

Tiryaki, Ş., Erdil, G., Acar, M., \& Emlek, Y. (1991). Sporcu ve sporcu olmayan gençlerin kişilik özellikleri. Spor Hekimliği Dergisi, 26(1), 19-23.

Voltan, N. (1980) Rathus Atılganlık Envanteri geçerlik ve güvenirlik çalışması. Psikoloji Dergisi, 10(1), 23-25.

Walsh, G., Sproule, L., McGuinness, C., Trew, K., Rafferty, H., \& Sheehy, N. (2006). An appropriate curriculum for 4-5-year-old children in Northern Ireland: comparing play-based and formal approaches. Early Years, 26(2), 201-221. https://doi.org/10.1080/09575140600760003

Weinberg, R. S., \& Gould, D. (2015). Spor ve egzersiz psikolojisinin temelleri (M. Şahin, Z. Koruç, Çev.). Ankara: Nobel Akademik Yayıncılık (Orijinal çalışma basım tarihi 2015).

Wolpe, J. (1968). Psychotherapy by reciprocal inhibition. Conditional reflex: a Pavlovian journal of research \& therapy, 3(4), 234-240. https://doi.org/10.1007/BF03000093

\section{Copyrights}

Copyright for this article is retained by the author(s), with first publication rights granted to the journal.

This is an open-access article distributed under the terms and conditions of the Creative Commons Attribution license (http://creativecommons.org/licenses/by/4.0/). 